\title{
Rapeseed meal of low- and high-glucosinolate type fed to growing-finishing pigs
}

\author{
MATTI NÄSI, TIMO ALAVIUHKOLA and KAIJA SUOMI \\ University of Helsinki, Department of Animal Husbandry, \\ SF-00710 HELSINKI \\ Agricultural Research Centre, Swine Research Station, \\ $S F-05840$ HYVINKÄ̈
}

\begin{abstract}
The nutritive value of five lots of rapeseed meal (RSM) from Brassica campestris or B. napus with different levels of glucosinolates (GL) was investigated in a digestibility and balance trial with a $5 \times 5$ Latin square design and in a growth trial with 140 growing-finishing pigs. The RSM's were prepared from the cultivars: Span-Torch, Sigga, Gulliver and Topas, and a heat-treated RSM was also studied, their total GL contents ( $\mu \mathrm{mol} / \mathrm{g}$ defatted meal) being $42,11,98,27$ and 8, respectively. Cv. Sigga had yellow hulls and a lower ADF content than the other cultivars. The hat-treated RSM had a reduced lysine content.

There were no significant $(\mathrm{P}>0.05)$ differences in organic matter or crude protein digestibilities between the RSM's with different GL levels or the RSM's prepared from $B$. campestris and $B$. napus, when RSM was used as the only protein supplement at a level of $20-25 \%$ in a barley-based diet. Heat treatment reduced the organic matter and crude protein digestibilities $(\mathrm{P}<0.01)$. Nitrogen retention and protein utilization were lower $(\mathrm{P}<0.01)$ on the diet supplemented with heat-treated RSM than on the diets with the other RSM's but otherwise there were no significant differences between them $(\mathrm{P}>0.05)$.

In the growth trial supplementation with HGL-RSM Gulliver (14\% in diet) caused some palatability problems and this led to reduced performance $(\mathrm{P}<0.05)$, but there were no differences between the other groups receiving 14-15\% RSM and the SBM control group $(\mathrm{P}>0.05)$. The carcass quality was similar in all the groups. The weight of the thyroid gland was higher in the pigs receiving RSM than in the SBM controls, by $6-57 \%(\mathrm{P}<0.05)$.

In the present study a fairly high RSM supplements from cultivars with a moderate high GL content could be used in the diet of growing pigs without impairing their performance, when the diet was formulated on the basis of the digestible nutrients of RSM. Heat-treated RSM, with protein of low rumen degradability, is of poor value in pig feeding due to the low digestibility and availability of its protein.
\end{abstract}

Index words: Rapeseed meal, glucosinolates, protein supplement, pig feeding, digestibility. 


\section{Introduction}

In Finland, production of rapeseed is one of the most readily available means of increasing the domestic supply of protein of high biological value for animal feeding. Rapeseed, both Brassica campestris and B. napus, is the only oil seed suitable for commercial cultivation in the climatic conditions of this country and its production has increased rapidly over the past decade. Rapeseed meal (RSM) contains $35-40 \%$ crude protein and RSM proteins have a well-balanced amino acid pattern, but their availability is rather low (SAUER et al. 1982). The antinutritional and toxic constituents of rapeseed are known greatly to restrict the utilization of RSM as a feed for monogastrics (BELL 1984). The fibre content of RSM is almost double that of soybean meal (SBM), which lowers the digestibility and feed value (SALo 1982).

The most important factor limiting the potential RSM as a protein supplement in pig feeding is the presence of glucosinolates (RUNDGREN 1983). Some of these are goitrogenic and others are potentially hepatotoxic, whilst the majority are volatile and have a strong bitter taste (BELL 1984). Meals prepared from rapeseed varieties with low or medium contents of glucosinolates are finding increased acceptance as a protein source in pig diets and are being used as a replacement for SBM (Alaviuhkola 1981, Salo 1982, THOMKE et al. 1983, Тномке 1984). The breeding work directed towards reduction of the hull content may also make RSM more suitable for pig feed. Some studies have shown that RSM may totally or partially replace SBM in growing-finishing pig diets without adverse effects of performance, while other studies have shown that complete or partial substitution of RSM for SBM affects pig performance adversely (RUNDGREN 1983).

The present study was conducted to compare the nutrient digestibility of rapeseed meals with different levels of glucosinolates and their effects on the performance of growing-finishing pigs. One of the RSM's was heat-treated in order to obtain information on the nutritive value on the RSM with low rumen - degradable protein in pig feeding.

\section{Materials and methods}

\section{Experimental feeds}

Two of the feeds from Brassica campestris were of Finnish origin: a commercial highglucosinolate rapeseed meal (HGRSM) prepared from cv. Span-Torch and a low-glucosinolate rapeseed meal (LGRSM) prepared from cv. Sigga. Two lots of B. napus meal were obtained from Sweden: HGRSM cv. Gulliver and LGRSM cv. Topas. One lot of B. napus meal was processed in Denmark to reduce the rumen degradability of the protein. The seeds were flaked, cooked, expelled through a press, extracted with hexane, desolvetized and toasted. The composition of the glucosinolates was as follows:

\begin{tabular}{lrrrrc} 
& \multicolumn{3}{c}{$\begin{array}{c}\text { B. campestris } \\
\text { Span }\end{array}$} & \multicolumn{3}{c}{ Sigga Gulliver Topas } \\
& & & & & $\begin{array}{c}\text { Heat } \\
\text { treat. }\end{array}$ \\
Gluconapin & 13.8 & 3.8 & 25.9 & 7.0 & 3.2 \\
Glucobrassicanapin & 11.2 & 2.2 & 5.8 & 2.2 & 2.1 \\
Progoitrin & 15.0 & 4.6 & 64.0 & 17.4 & 3.1 \\
Napoleiferin & 2.2 & 0.5 & 2.2 & 0.5 & 0
\end{tabular}

Concentrations expressed as $\mu \mathrm{mol} / \mathrm{g}$ defatted meal Analysis made at University of Technology, Department of Chemistry by courstesy of Dr. Anneli Hase.

\section{Digestibility and balance trial}

The experiment involved five isonitrogenous, $16 \%$ crude protein diets, in which RSM's of HG or LG types were used as protein supplements. The diets were enriched with $40 \mathrm{~g} / \mathrm{d}$ mineral mixture and $15 \mathrm{~g} / \mathrm{d}$ vitamin mixture and had the following composition:

$\begin{array}{lccc}\text { Diet } & \text { Barley } & \text { RSM } & \text { Starch } \\ \text { 1. HGRSM Span-Torch } & 75.0 & 25.0 & 0.0 \\ \text { 2. LGRSM Sigga } & 75.0 & 25.0 & 0.0 \\ \text { 3. HGSRM Gulliver } & 75.0 & 21.9 & 3.1 \\ \text { 4. LGRSM Topas } & 75.0 & 20.2 & 4.8 \\ \text { 5. LGRSM Heat-treat. } & 75.0 & 21.5 & 3.5\end{array}$


Five crossbred barrows, weighing $29 \mathrm{~kg}$ initially and $71 \mathrm{~kg}$ finally, were rotated through five successive feeding periods in a $5 \times 5$ Latin square arrangement. One pig was fed on only barley plus minerals, to obtain the basal diet digestibilities. Each period comprised 6 days of adjustment and 6 days of faecal and urine collection, as described by NÄsı (1984). The coefficients of the apparent digestibility of the nutrients and the nitrogen balance were calculated for each diet and, using the difference method, for each RSM, too. The digestibility coefficients were analysed statistically as a Latin square design.

\section{Growth trial}

A hundred and forty cross-bred Landrace and Large White pigs averaging $25 \mathrm{~kg}$ live weight were allotted to five experimental groups on the basis of litter origin, sex and initial live weight. Each group consisted of 14 replicates of two pair-fed pigs. The diets were formulated to contain $135 \mathrm{~g} \mathrm{DCP} / \mathrm{FU}$ and minerals and vitamins according to the requirements (SALo et al. 1982). The five formulas, in which the rapeseed meals replaced soybean meal had the following dietary composition:

\begin{tabular}{lrrrrrr} 
& \multicolumn{9}{c}{ B. campestris } & \multicolumn{3}{c}{ B. napus } \\
Ingredients & $0-$ & 00- & \multicolumn{1}{c}{0 - } & 00- & Control \\
& rape & rape & rape & rape & SBM \\
Barley & 77.5 & 77.5 & 78.5 & 78.5 & 82.5 \\
HGRSM Span- & & & & & \\
Torch & 15.0 & - & & & \\
LGRSM Sigga & - & 15.0 & - & - & - \\
HGRSM Gulliver & - & - & 14.0 & - & - \\
LGRSM Topas & - & - & - & 14.0 & - \\
Soybean meal & 1.0 & 1.0 & 1.0 & 1.0 & 11.0 \\
Fish meal & 3.0 & 3.0 & 3.0 & 3.0 & 3.0 \\
Min. vit. mix. & 3.5 & 3.5 & 3.5 & 3.5 & 3.5 \\
FU/kg feed & 0.926 & 0.933 & 0.930 & 0.931 & 0.964 \\
DCP/FU, g & 137 & 134 & 138 & 140 & 136
\end{tabular}

The pigs were fed according to a weightbased restricted feeding scale (SALO et al. 1982). Individual live weights and feed consumption on a pen basis were recorded at weekly intervals. The pigs were sent to slaugh- ter when they reached $95 \mathrm{~kg}$ live weight. The carcass evaluation was made by measuring the ratio of lean to fat, the colour of the lean and $\mathrm{pH}$. The thyroid weights were also determined on the recovered portion of $50-67 \%$ of the pigs in the different groups.

\section{Results and discussion}

The total glucosinolate levels $(\mu \mathrm{mol} / \mathrm{g}$ defatted meal) of the rapeseed meals investigated in this study were: B. campestris - SpanTorch 42.2 (HGRSM) and Sigga (LGRSM) 11.1 and for B. napus - Gulliver 97.9 (HGRSM), Topas 27.1 (LGRSM) and heat treated RSM 8.4. The Finnish commercial RSM originates mainly from $B$. campestris cultivars Span, Torch and Emma, which have much lower total glucosinolate contents less than B. napus $\mathrm{HG}$ types. The content of nitrils was $1.7 \mu \mathrm{mol} / \mathrm{g}$ in meal from Sigga and $2.1-2.6$ in the other RSM's.

In the RSM's originating from $B$. campestris the crude protein content was $7 \%$ units lower and the fat left in solvetizing was $10 \%$, the process thus differing between the various RSM's (Table 1). Crude fibre was at the same level in all the RSM's except cv. Topas, in which it was a little lower. Cv. Sigga is a yellow thin-coated type, but had no difference in crude fibre (Table 1). However, the analysis for acid detergent fibre and acid detergent lignin showed that Sigga had one quarter less $\mathrm{ADF}$ and only half the $\mathrm{ADL}$ value than the others. The hulls from yellow cultivars contain less crude fibre than those from the dark cultivars (Stringham et al. 1974, Bell and SHIREs 1982). The yellow hulls have a higher amount of polysaccharides and less polyphenols than the dark hulls (THEANDER et al. 1977).

The amino acid composition was fairly similar in the different RSM's (Table 1). Heattreated RSM had a reduced lysine content, the available lysine being especially low, $2.6 \mathrm{~g} / 16$ g N vs. $4.1-4.2$ in the other RSM's. The rumen degradability of the heat-treated RSM 
Table 1. Chemical composition of rapeseed meals from different cultivars.

\begin{tabular}{|c|c|c|c|c|c|}
\hline & \multicolumn{2}{|c|}{ B. campestris } & \multicolumn{3}{|c|}{ B. napus } \\
\hline & $\begin{array}{l}\text { HGRSM } \\
\text { Span-Torch }\end{array}$ & $\begin{array}{l}\text { LGRSM } \\
\text { Sigga }\end{array}$ & $\begin{array}{l}\text { HGRSM } \\
\text { Gulliver }\end{array}$ & $\begin{array}{l}\text { LGRSM } \\
\text { Topas }\end{array}$ & $\begin{array}{c}\text { LGRSM } \\
\text { Heat treated }\end{array}$ \\
\hline Dry matter \% & 88.4 & 89.6 & 89.3 & 89.0 & 86.3 \\
\hline Ash, $\%$ & 7.3 & 7.3 & 7.4 & 7.4 & 7.5 \\
\hline Crude protein, \% & 35.2 & 34.0 & 39.6 & 43.1 & 41.9 \\
\hline True protein, \% & 30.9 & 31.3 & 33.2 & 39.5 & 38.6 \\
\hline Ether extract, \% & 7.9 & 12.3 & 1.9 & 3.0 & 4.6 \\
\hline Crude fibre, $\%$ & 15.7 & 16.7 & 16.1 & 12.6 & 15.1 \\
\hline Nitrogen free extract, \% & 33.9 & 29.8 & 35.0 & 34.0 & 30.9 \\
\hline Acid detergent fibre, $\%$ & 21.4 & 15.1 & 20.9 & 18.9 & 21.7 \\
\hline Neutral detergent fibre, $\%$ & 24.7 & 30.0 & 26.0 & 24.8 & 30.5 \\
\hline Acid detergent lignin, $\%$ & 10.0 & 4.6 & 9.4 & 9.1 & 11.0 \\
\hline Total glucosinolates $\mu \mathrm{mol} / \mathrm{g}$ & 42.2 & 11.1 & 97.9 & 27.1 & 8.4 \\
\hline Progoitrin, $\mu \mathrm{mol} / 1$ & 15.0 & 4.6 & 64.0 & 17.4 & 3.1 \\
\hline Tannin, $\%$ & 1.4 & 1.7 & 1.6 & 1.8 & 1.5 \\
\hline \multicolumn{6}{|l|}{ Amino acids, $\mathrm{g} / 16 \mathrm{~g} \mathrm{~N}$} \\
\hline Alanine & 4.3 & 4.1 & 4.2 & 4.2 & 4.1 \\
\hline Arginine & 6.6 & 6.3 & 6.9 & 7.2 & 6.3 \\
\hline Aspartic acid & 6.5 & 7.8 & 6.5 & 6.9 & 7.9 \\
\hline Cystine & 1.3 & 1.5 & 1.7 & 1.4 & 1.2 \\
\hline Glutamic acid & 20.3 & 20.2 & 20.0 & 20.6 & 18.3 \\
\hline Glycine & 5.7 & 5.4 & 5.6 & 5.7 & 5.4 \\
\hline Histidine & 2.6 & 2.9 & 2.9 & 3.3 & 2.8 \\
\hline Isoleucine & 4.2 & 3.9 & 3.9 & 4.2 & 4.3 \\
\hline Leucine & 7.1 & 6.2 & 6.4 & 6.5 & 7.1 \\
\hline Lysine & 6.3 & 5.5 & 6.5 & 6.0 & 4.6 \\
\hline Methionine & 1.1 & 1.2 & 1.1 & 1.2 & 1.3 \\
\hline Phenylalanine & 3.8 & 3.5 & 3.5 & 3.3 & 3.7 \\
\hline Proline & 6.7 & 5.9 & 7.0 & 6.6 & 6.0 \\
\hline Serine & 4.7 & 4.4 & 4.5 & 4.4 & 4.3 \\
\hline Threonine & 4.7 & 4.5 & 4.7 & 4.6 & 4.5 \\
\hline Tyrosine & 2.8 & 3.0 & 2.7 & 2.8 & 3.0 \\
\hline Valine & 5.1 & 5.0 & 4.9 & 5.1 & 5.1 \\
\hline Available lysine & 4.2 & 4.1 & 4.4 & 4.4 & 2.6 \\
\hline
\end{tabular}

protein was $30 \%$, as opposed to $50-60 \%$ in the other RSM when measured in sacco for $18 \mathrm{~h}$ in the rumen (NÄsı 1984). The heat treatment was evidently rather strong, since the degradability of the other RSM protein was already low after the normal meal processing. The content of sulphur amino acids in the RSM's was rather low in the present study, compared for example, with the results of BELL (1984).

The digestibility coefficients of the nutrients of the different RSM's calculated by the difference method are shown in Table 2. There was no significant $(\mathrm{P}>0.05)$ difference in the organic matter $(61-70 \%)$ or crude protein digestibilities (70-74 \%) between HGRSM's and LGRSM's or between B. campestris and
B. napus, but the B. napus meal had lower organic matter digestibility due to its lower fat content, while fat was digested fairly efficiently. According to the literature, HGRSM organic matter has a digestibility of $67-69$ and that of LGRSM $70-84 \%$, and the digestibility of their crude protein is $67-80$ and $72-86$, respectively (RUNDGREN 1983). The heat treatment reduced the digestibility of organic matter and crude protein significantly $(\mathrm{P}<0.05)$. The heat treatment was evidently rather hard, which decreased the digestibility and availability.

The RSM's from B. campestris had higher feed values because of their higher fat content, $0.96-0.87 \mathrm{FU} / \mathrm{kg}$ DM vs. $0.74-0.70$ of RSM from B. napus. 
Table 2. Digestibility coefficients of nutrients from different rapeseed meals and their calculated feed values.

\begin{tabular}{|c|c|c|c|c|c|c|c|c|c|c|}
\hline & \multicolumn{4}{|c|}{ B. campestris } & \multicolumn{6}{|c|}{ B. napus } \\
\hline & \multicolumn{2}{|c|}{$\begin{array}{c}\text { HGRSM } \\
\text { Span-Torch }\end{array}$} & \multicolumn{2}{|c|}{$\begin{array}{l}\text { LGRSM } \\
\text { Sigga }\end{array}$} & \multicolumn{2}{|c|}{$\begin{array}{c}\text { HGRSM } \\
\text { Gulliver }\end{array}$} & \multicolumn{2}{|c|}{$\begin{array}{c}\text { LGRSM } \\
\text { Topas }\end{array}$} & \multicolumn{2}{|c|}{$\begin{array}{c}\text { LGRSM } \\
\text { Heat treated }\end{array}$} \\
\hline & $\overline{\mathrm{X}}$ & s.d. & $\bar{x}$ & s.d. & $\bar{x}$ & s.d. & $\bar{x}$ & s.d. & $\overline{\mathrm{X}}$ & s.d. \\
\hline \multicolumn{11}{|l|}{ Digestibilities } \\
\hline Dry matter & $65.0^{\mathrm{ab}}$ & 9.3 & $65.5^{\mathrm{a}}$ & 4.2 & $57.1^{\mathrm{ab}}$ & 6.4 & $60.9^{\mathrm{ab}}$ & 3.8 & $54.0^{b}$ & 8.4 \\
\hline Ash & $35.4^{a}$ & 17.3 & $23.9^{\mathrm{a}}$ & 5.1 & $25.7^{\mathrm{a}}$ & 11.6 & $36.3^{\mathrm{a}}$ & 6.9 & $26.8^{a}$ & 7.1 \\
\hline Organic matter & $68.4^{\mathrm{ab}}$ & 8.6 & $69.8^{\mathrm{a}}$ & 3.9 & $60.7^{\mathrm{ab}}$ & 5.2 & $63.9^{\mathrm{ab}}$ & 3.8 & $57.7^{\mathrm{b}}$ & 7.1 \\
\hline Crude protein & $73.7^{\mathrm{a}}$ & 5.4 & $70.9^{a}$ & 3.1 & $70.1^{a}$ & 5.3 & $73.4^{\mathrm{a}}$ & 4.5 & $68.7^{a}$ & 6.9 \\
\hline Ether extract & $56.7^{\mathrm{ab}}$ & 17.6 & $75.1^{\mathrm{a}}$ & 9.6 & \multicolumn{2}{|c|}{ neg } & $5.4^{\mathrm{b}}$ & 42.4 & $49.6^{\mathrm{ab}}$ & 16.9 \\
\hline Crude fibre & $51.7^{\text {abde }}$ & 17.3 & $66.2^{\text {ad }}$ & 13.2 & $40.5^{\text {abde }}$ & 15.7 & $34.8^{\text {bde }}$ & 10.4 & $25.0^{\text {be }}$ & 15.5 \\
\hline \multicolumn{11}{|l|}{ Nitrogen free } \\
\hline extract & $72.7^{a}$ & 10.8 & $67.7^{a}$ & 8.8 & $66.8^{a}$ & 9.1 & $67.2^{\mathrm{a}}$ & 9.4 & $59.3^{\mathrm{a}}$ & 5.8 \\
\hline \multicolumn{11}{|l|}{ Feed values } \\
\hline FU/kg DM & \multicolumn{2}{|c|}{0.870} & \multicolumn{2}{|c|}{0.958} & \multicolumn{2}{|c|}{0.724} & \multicolumn{2}{|c|}{0.741} & \multicolumn{2}{|c|}{0.698} \\
\hline $\mathrm{kg} / \mathrm{FU}$ & \multicolumn{2}{|c|}{1.30} & \multicolumn{2}{|c|}{1.17} & \multicolumn{2}{|c|}{1.55} & \multicolumn{2}{|c|}{1.52} & \multicolumn{2}{|c|}{1.66} \\
\hline DCP $\%$ in DM & \multicolumn{2}{|c|}{25.9} & \multicolumn{2}{|c|}{24.1} & \multicolumn{2}{|c|}{27.8} & \multicolumn{2}{|c|}{31.6} & \multicolumn{2}{|c|}{28.0} \\
\hline $\mathrm{g} \mathrm{DCP} / \mathrm{FU}$ & \multicolumn{2}{|c|}{298} & \multicolumn{2}{|c|}{252} & \multicolumn{2}{|c|}{384} & \multicolumn{2}{|c|}{427} & \multicolumn{2}{|c|}{413} \\
\hline MJ, ME/kg DM (Just) & \multicolumn{2}{|c|}{12.87} & \multicolumn{2}{|c|}{14.01} & 11.0 & & 11. & & 10.8 & \\
\hline MJ, NE/kg DM " & 7.7 & & 8. & & 6.4 & & 6. & 73 & 6.2 & 22 \\
\hline $\mathrm{FU}, \mathrm{NE} / \mathrm{kg} \mathrm{DM} \quad "$ & 1.0 & & 1. & & 0.8 & & 0.8 & 87 & 0.8 & 81 \\
\hline MJ, ME/kg DM (Axelsson) & 11.9 & & 12. & & 10.3 & & 10. & & 10. & \\
\hline
\end{tabular}

Means with different letters were significantly different $(a-c P<0.05, d-f P<0.01)$

Table 3. Nitrogen balance and biological value of diets including rapeseed meals from different cultivars and daily gain of pigs.

\begin{tabular}{|c|c|c|c|c|c|c|c|c|c|c|}
\hline & \multicolumn{4}{|c|}{ B. campestris } & \multicolumn{6}{|c|}{ B. napus } \\
\hline & \multicolumn{2}{|c|}{$\begin{array}{c}\text { HGRSM } \\
\text { Span-Torch }\end{array}$} & \multicolumn{2}{|c|}{$\begin{array}{c}\text { LGRSM } \\
\text { Sigga }\end{array}$} & \multicolumn{2}{|c|}{$\begin{array}{c}\text { HGRSM } \\
\text { Gulliver }\end{array}$} & \multicolumn{2}{|c|}{$\begin{array}{l}\text { LGRSM } \\
\text { Topas }\end{array}$} & \multicolumn{2}{|c|}{$\begin{array}{c}\text { LGRSM } \\
\text { Heat treated }\end{array}$} \\
\hline & $\overline{\mathrm{X}}$ & s.d. & $\bar{x}$ & s.d. & $\bar{x}$ & s.d. & $\bar{x}$ & s.d. & $\bar{x}$ & s.d. \\
\hline $\mathrm{N}$ intake, $\mathrm{g} / \mathrm{d}$ & $42.4^{\mathrm{a}}$ & 11.1 & $41.9^{a}$ & 10.9 & $42.3^{\mathrm{a}}$ & 11.0 & $41.8^{\mathrm{a}}$ & 10.8 & $42.5^{\mathrm{a}}$ & 11.0 \\
\hline $\mathrm{N}$ excreted in faeces, $\mathrm{g} / \mathrm{d}$ & $10.9^{\mathrm{ab}}$ & 2.6 & $11.4^{\mathrm{ab}}$ & 2.5 & $11.6^{\mathrm{ab}}$ & 2.5 & $10.7^{b}$ & 2.1 & $11.9^{\mathrm{a}}$ & 2.1 \\
\hline $\mathrm{N}$ absorbed, g/d & $31.5^{\mathrm{a}}$ & 8.7 & $30.6^{\mathrm{a}}$ & 8.5 & $30.7^{\mathrm{a}}$ & 8.7 & $31.1^{\mathrm{a}}$ & 8.8 & $30.7^{a}$ & 9.1 \\
\hline $\mathrm{N}$ excreted in urine, $\mathrm{g} / \mathrm{d}$ & $11.6^{\mathrm{b}}$ & 3.4 & $11.8^{b}$ & 3.8 & $11.6^{\mathrm{b}}$ & 4.0 & $12.2^{\mathrm{ab}}$ & 4.4 & $13.7^{\mathrm{a}}$ & 4.9 \\
\hline $\mathrm{N}$ retained, $\mathrm{g} / \mathrm{d}$ & $20.0^{\mathrm{d}}$ & 5.4 & $18.8^{\mathrm{d}}$ & 4.7 & $19.1^{\mathrm{d}}$ & 4.8 & $18.8^{\mathrm{d}}$ & 4.6 & $16.9^{\mathrm{e}}$ & 4.3 \\
\hline - $\%$ of intake & $46.9^{d}$ & 1.2 & $45.0^{d}$ & 0.8 & $45.2^{\mathrm{d}}$ & 2.7 & $45.2^{\mathrm{d}}$ & 2.1 & $39.8^{\mathrm{e}}$ & 1.9 \\
\hline - $\%$ of absorption & $63.4^{\mathrm{d}}$ & 2.0 & $61.9^{d}$ & 2.1 & $62.6^{\mathrm{d}}$ & 3.0 & $61.1^{\mathrm{d}}$ & 3.2 & $55.8^{\mathrm{e}}$ & 2.9 \\
\hline $\mathrm{N}$ retained, $\mathrm{g} / \mathrm{kg} \mathrm{W}^{0.75} / \mathrm{d}$ & $1.10^{\mathrm{ad}}$ & 0.06 & $1.01^{\text {bde }}$ & 0.08 & $1.05^{\text {abd }}$ & 0.10 & $1.03^{\text {bde }}$ & 0.09 & $0.93^{\text {ce }}$ & 0.07 \\
\hline Urea excreted, g/d & $19.7^{\text {be }}$ & 6.4 & $19.7^{\mathrm{be}}$ & 6.8 & $18.4^{\text {be }}$ & 7.3 & $20.1^{\text {bde }}$ & 8.2 & $24.9^{\text {ad }}$ & 8.9 \\
\hline Urea excreted, g/kg W0.75/d & $1.08^{\mathrm{e}}$ & 0.18 & $1.07^{e}$ & 0.13 & $0.99^{f}$ & 0.21 & $1.08^{\mathrm{e}}$ & 0.24 & $1.34^{\mathrm{d}}$ & 0.23 \\
\hline Creatinine excreted, $\mathrm{g} / \mathrm{d}$ & $1.71^{\mathrm{a}}$ & 0.51 & $1.73^{\mathrm{a}}$ & 0.71 & $1.67^{a}$ & 0.56 & $1.66^{\mathrm{a}}$ & 0.53 & $1.59^{\mathrm{a}}$ & 0.48 \\
\hline Biological value & $71.2^{\mathrm{d}}$ & 2.2 & $70.1^{d}$ & 2.3 & $70.7^{d}$ & 3.1 & $69.3^{\mathrm{d}}$ & 3.3 & $64.5^{e}$ & 3.4 \\
\hline Daily gain, g/d & $687^{a}$ & 84 & $656^{a}$ & 149 & $693^{a}$ & 147 & $604^{a}$ & 151 & $645^{a}$ & 213 \\
\hline
\end{tabular}

Means with different letters were statistically significant $(a-c P<0.05 ; d-f P<0.01)$

Table 3. presents data on the nitrogen balance and protein utilization. The differences between $\mathrm{HG}$ and LG rape types were small and also those between the two Brassica spe- cies $(\mathrm{P}>0.05)$. Heat treatment reduced nitrogen retention and protein utilization $(\mathrm{P}<$ $0.01)$. $\mathrm{N}$ retention calculated as $\mathrm{g} / \mathrm{kg} \mathrm{W}^{0.75}$ was lower in RSM from Sigga and Topas than 
Table 4. Growth rate, feed utilization and carcass quality of pigs on diets in which soybean meal was replaced with different types of rapeseed meal.

\begin{tabular}{|c|c|c|c|c|c|}
\hline \multirow[t]{2}{*}{ Diets } & \multicolumn{2}{|c|}{ B. campestris } & \multicolumn{2}{|c|}{ B. napus } & \multirow[b]{2}{*}{$\begin{array}{c}\text { Control } \\
\text { SBM }\end{array}$} \\
\hline & $\begin{array}{c}\text { HGRSM } \\
\text { Span }\end{array}$ & $\begin{array}{c}\text { LGRSM } \\
\text { Sigga }\end{array}$ & $\begin{array}{c}\text { HGRSM } \\
\text { Gulliver }\end{array}$ & $\begin{array}{c}\text { LGRSM } \\
\text { Topas }\end{array}$ & \\
\hline Initial weight, kg & 25.0 & 25.0 & 25.0 & 24.8 & 25.0 \\
\hline Final weight, kg (corr.) & 96.0 & 96.8 & 96.6 & 96.4 & 97.2 \\
\hline Loss at slaughter, $\%$ & 28.4 & 28.3 & 29.2 & 28.5 & 27.4 \\
\hline Daily weight gain, g & $771^{\text {ab }}$ & $796^{\mathrm{b}}$ & $747^{a}$ & $777^{\mathrm{ab}}$ & $787^{b}$ \\
\hline FU/pig/d & 2.13 & 2.19 & 2.12 & 2.17 & 2.16 \\
\hline $\mathrm{FU} / \mathrm{kg}$ gain & 2.78 & 2.75 & 2.85 & 2.81 & 2.75 \\
\hline $\mathrm{Kg} \mathrm{DM} / \mathrm{kg}$ gain & $2.57^{\mathrm{ab}}$ & $2.54^{\mathrm{ab}}$ & $2.65^{a}$ & $2.59^{\mathrm{ab}}$ & $2.44^{b}$ \\
\hline Side fat, mm & 16.8 & 16.8 & 16.7 & 17.0 & 17.9 \\
\hline Eye, muscle area, $\mathrm{cm}^{2}$ & 38.0 & 38.7 & 37.5 & 37.3 & 39.3 \\
\hline Colour of lean (points $1-5$ ) & 2.4 & 2.4 & 2.5 & 2.5 & 2.3 \\
\hline Meat in valuable cuts, \% & 80.6 & 80.8 & 80.7 & 80.6 & 80.9 \\
\hline Thyroid gland, g & $8.8^{\mathrm{ab}}$ & $8.4^{\mathrm{ab}}$ & $12.4^{\mathrm{a}}$ & $9.4^{\mathrm{ab}}$ & $7.9^{\mathrm{b}}$ \\
\hline Thyroid gland, rel. & (111) & (106) & (157) & (119) & (100) \\
\hline
\end{tabular}

Means with different letters were significantly different $(a-b P<0.05)$

in RSM from Span-Torch $(\mathrm{P}<0.05)$, and heat-treated RSM had a lower value than all the other RSM's $(\mathrm{P}<0.05,0.01)$. The urea excretion, which gives an indication of the amino acid balance in the diet, accorded with the nitrogen retention results; heat treatment of RSM increased urea excretion $(\mathrm{P}<0.01)$. The biological values of the various RSM diets were quite close to each other (69-71), but in the diet supplemented with heat-treated RSM this value was significantly reduced $(\mathrm{P}<0.01)$. The daily gains recorded after each 12-day balance trial were $600-690 \mathrm{~g}$ and differences between the treatments were small $(\mathrm{P}>0.05)$.

In the growth trial palatability problems occurred in the groups receiving RSM derived from Gulliver and slight problems in the groups given Span-Torch meal, so that the daily allowances had to be temporarily reduced. This was partly reason for the lower performance of the HGRSM Gulliver group $(\mathrm{P}<0.05)$. There were no differences in daily gain between the other RSM groups and the control group receiving SBM. The group receiving LGRSM Sigga performed fairly well; the daily gain was $796 \mathrm{~g}$, as against the control value of $787 \mathrm{~g}$, and the feed conversion efficiency was the same for the two groups, $2.75 \mathrm{FU} / \mathrm{kg}$ gain.

The carcass quality was similar in all the groups $(\mathrm{P}>0.05)$. The weight of the thyroid gland was elevated in pigs receiving RSM compared to the control value. HGRSM Gulliver gave an increase of $57 \%$, while in the others it was 6 to $19 \%(\mathrm{P}<0.05)$. These results are in accordance with the progoitrin content of the RSM's.

Acknowledgements. The authors are indebted to Ms. Eija Lämsä, M.Sc. \& Agr., for technical assistance and to Öljynpuristamo Oy for financial support.

\section{References}

Alaviunkola, T. 1982. Rypsirouheen kăyttömahdollisuudet sikataloudessa. Sika No 2: 10-11.

BELl, J.M. 1984. Nutrients and toxicants in rapeseed meal: a review. J. Anim. Sci. 58: 996-1010.
— \& ShIRES, A. 1982. Composition and digestibility by pigs of hull fractions from rapeseed cultivars with yellow or brown seed coats. Can. J. Anim. Sci. 62: 557-565. NĀsı, M. 1984 a. Nutritive value and metabolic effects 
of whey protein concentrate and hydrolysed lactose for growing pigs. J. Agric. Sci. Finl. 56: 227-238.

- 1984 b. Eri rypsi- ja rapsilajikkeiden hyvăksikăyttő lihasialla. Suomen Maataloustieteellisen Seuran Tiedote No 4: 52-58.

RUNDGREN, M. 1983. Low-glucosinolate rapeseed products for growing pigs - a review. Anim. Feed Sci. Technol. 9: 239-263.

SALO, M-L. 1982. Rapeseed meal as a protein source for growing pigs. J. Scient. Agric. Soc. Finl. 54: 313-320.

-, TUORI, M. \& KIISKInen, T. 1982. Rehutaulukot ja ruokintanormit. 70 p. Helsinki.

Sauer, W.C., Cichon, R. \& Misir, R. 1982. Amino acid availability and protein quality of canola meal and rapeseed meal for pigs and rats. J. Anim. Sci. 54: 292-301.

Stringham, G.R., McGregor, D.I. \& Pawlowski, S.H.
1974. Chemical and morphological characteristics associated with seed coat color in rapeseed. Proc 4 th Int Rapeseed Conf. Giessen. pp. 99-108.

Theander, O., Ȧhman, P., Mische, G.E. \& Yasuda, S. 1977. Carbohydrates, polyphenols and lignin in seed hulls of different colors from turnip rapeseed. J. Agric. Food Chem. 25: 270-273.

TномкE, S. 1984. Further experiments with RSM of Swedish low-glucosinolate type fed to growing-finishing pigs. Swedish J. Agric. Sci. 14: 151-157.

-, Elwinger, K., Rundgren, M. \& Ahlstróm, B. 1983. Rapeseed meal of Swedish low-glucosinolate type fed to broiler chickens, laying hens and growing-finishing pigs. Acta Agric. Scand. 33: 75-96.

Ms received September 30, 1985

\section{SELOSTUS}

\section{Runsaasti ja vähän glukosinolaatteja sisältävät rypsi- ja rapsirouheet lihasikojen valkuaisenlähteenä}

\author{
Matti Näsi, Timo Alaviuhkola \\ ja Kaija Suomi
}

Helsingin yliopisto, kotieläintieteen laitos, $00710 \mathrm{Helsinki}$

Maatalouden tutkimuskeskus, sikatalouden tutkimusasema, 05840 Hyvinkää

Sulavuus- ja tasekokeessa sekä kasvatuskokeessa tutkittiin kahden rypsirouheen Brassica campestris ja kolmen rapsirouheen $\boldsymbol{B}$. napus arvoa lihasikojen valkuaislähteenả. Rouheista oli kaksi runsaasti glukosinolaatteja sisaaltäviaa, lajikkeet Span-Torch (0-rypsi) ja Gulliver (0-rapsi) ja kaksi văhăn glukosinolaatteja sisältăviă Sigga (00-rypsi) ja Topas (00-rapsi) sekă yksi lämpökäsitelty rapsirouhe. 00-rypsi Sigga oli keltasiemeninen ohutkuorinen tyyppi, jonka happodetergentti kuidun pitoisuus oli 3/4 osaa muiden rouheiden arvosta. Sulavuus- ja tasekokeessa $(5 \times 5$ latinalainen neliö) $\mathrm{rypsi} / \mathrm{rapsirouhe}$ oli yksinomaisena valkuaislisănă, $20.2-25.0 \%$ dieetistă. 0 -rypsin ja 00-rypsin tai -rapsien vălillă ei ollut merkitseviă eroja eri ravintoaineiden sulavuuksien vălillă raakakuitua ja -rasvaa lukuunottamatta. Eri rouheiden koostumus oli kuitenkin erilainen mm. rypsirouheissa oli ras- vaa n. $10 \%$ kun rapsirouheisiin oli jätetty vain $3 \%$. Lämpökäsitelty rapsirouhe oli sulavuudeltaan merkitsevästi muita rouheita huonompaa. Rypsirouheiden ry-arvo oli $0.87-0.96$ ja rapsirouheiden $0.70-0.74 \mathrm{~kg} / \mathrm{ry}$ eron johtuessa pääasiassa erilaisesta rasvapitoisuudesta.

Kasvatuskokeessa rypsi/rapsirouheen osuus dieetissä oli 14-15\% ja vertailuseoksessa oli soijarouhetta. Kaikissa koeryhmissă oli 28 eläintă, jotka ruokittiin yhdellă seoksella (135 g srv/ry) koko kasvatuskauden, 25-95. 00-rapsia saaneilla elăimillă esiintyi jonkin verran syömăttömyyttä. Lisăkasvu oli merkitsevästi tăllă ryhmällă alempi kuin muilla. Rehun hyväksikäytössä (ry/kg lisäkasvua) ei ollut ryhmien vălillă tilastollisesti merkitseviă eroja, ei myöskaaăn teuraslaadussa. Kilpirauhasen paino oli kaikilla rypsi/rapsirouhetta saaneilla elăimillă suurempi kuin soijaryhmaan eläimillaa. 